\title{
EAl Endorsed Transactions

\section{To be or not to be - a data set. Art, technology and identity in the new informational order}

\author{
F. $\operatorname{Costa}^{1, *}$ \\ ${ }^{1}$ Conicet-IDAES and Universidad de Buenos Aires, Argentina
}

\section{Abstract}

In recent decades, a significant part of public and private governmental efforts has been devoted to developing technologies to collect and analyze data about living beings. On the one hand, data on their biological endowments, such as in biometrics or measurements of organic processes with biomedicine devices. On the other hand, data about their "forms of life": habits, opinions, even emotions, such as in data mining. Between "fingerprint" and "digital footprint", then, is stretched out one of the main lines of force of the techno-scientific intelligibility grid about what we are and what we could be. I will discuss three strategies with which some contemporary artists appropriate the new technologies for recording information from living bodies to unveil critically the mechanisms of capture of individuals and individuations they realize. In the end, I will resituate this question: what is at stake in the incitement to understand ourselves as a "data set"?

Keywords: art, technology, identity.

Received on 07 January 2020, accepted on 14 January 2020, published on 22 January 2020

Copyright (C) 2020 F. Costa et al., licensed to EAI. This is an open access article distributed under the terms of the Creative Commons Attribution licence (http://creativecommons.org/licenses/by/3.0/), which permits unlimited use, distribution and reproduction in any medium so long as the original work is properly cited.

doi: 10.4108/eai.2-4-2020.163848

${ }^{*}$ Corresponding author. Email: flavc@hotmail.com

\section{Introduction}

In recent decades ${ }^{2}$, a significant part of public and private governmental efforts has been devoted to developing technologies to collect and analyze data about living beings. On the one hand, data about their biological endowments, to measure their biometrics or store their data in genetic data

\footnotetext{
${ }^{2}$ The author is $\mathrm{PhD}$ in Social Sciences at the University of Buenos Aires, where she has worked as a professor since 1995 at the Faculty of Social Sciences. An adjunct researcher at CONICET (National Council for Technical and Scientific Research), located at the Instituto de Altos Estudios Sociales of the Universidad Nacional de San Martín. She is a member of the editorial board of Artefacto. Pensamientos sobre la técnica, as well as the collective Ludion - Exploratorio latinoamericano de poéticas/políticas tecnológicas (www.ludion.org). She has been one of the translators of Giorgio Agamben's work to Spanish for more than a decade.
}

banks. On the other hand, data about their "forms of life": consumption habits, affective relations, opinions and even emotions about different events, through data mining aimed at commercial or political marketing, for example.

At one of its poles, the meticulous identification of bodies; at the other, the elaboration of behavioral profiles based on statistical correlations that are simple "given". On the one hand, the actual or possible observation of a biological individual; on the other, the construction, not of a representation, but of a statistical simulation of what an identity could be, acting as a reductive but hugely effective mirror.

Between "biological registry" and "algorithmic control" is stretched out, then, one of the main lines of force of the techno-scientific and governmental intelligibility grid about what we are and what we could be.

On this communication, I will comment three different strategies with which some contemporary artists appropriate the new technologies for recording information from living bodies (biometric or behavioral data, measurements of 
organic processes with biomedicine devices) to unveil critically the mechanisms of capture of individuals and individuations that they realize. In the end, I will resituate this question: what is at stake in the incitement to understand ourselves as a "data set"?

\section{Omnes et singulatim in the new informational order ${ }^{3}$}

From the perspective of the research on governmentality, in which this writing is situated, one of the strong thesis that guides the cartography of our present is that we are facing, at least since the seventies, a new order. A new informational order that implies the extension of the biopolitical battlefield. On the current scenario, power on life starts on the genetical information of the living and its controlled manipulation, up to the governance of the audiences, their emotions, their affections, their every-day decisions. The species and the audiences, the two poles of population as described by Foucault in Security, Territory, Population: "Population [...] is everything that will extend from the biological root expressed by the species up until the grip hold presented by the audience" (p. 102) [2]. We know a visible part of the history of this new general informational order through the history of a series of companies and products. We see only some of these proper names. In 1994, both Yahoo and Amazon were created; in 1997, Google, Blogger and Netflix; in 1999, Napster; in 2001, iTunes; in 2004, MySpace; in 2004, Facebook; in 2005, YouTube; in 2006, Twitter, Spotify and Waze; in 2007, the iPhone and the Kindle; in 2008, Airbnb; in 2010, Instagram and Über; in 2011, Snapchat; in 2012, Tinder; in 2013, Cambridge Analytica; in 2014, Happn; in 2015, Alphabet.

We know less, in exchange, about how many of these companies transformed into key pieces in the exercise of a double sided governmentality. On one side, totalizing, probabilistic, creative and conditioner for the "medium" in which the elements could circulate, aimed at the management of audience-populations (targets). And at the same time, individualizing and surveilling, able to reconduct from those audiences to the individuals. The process is deployed through six groups of actions reaching from the micro level of the individual-end user to the macro level of global statistics, and back again to the individual: data capture (registry), information processing and its analysis to produce data bases (serialization), development and analysis of statistics (totalization), profile building (targetting or segmentation), authentication (identity verification) and identification (individualization).

\footnotetext{
3 I recover some ideas of my text "Omnes et singulatim en el Nuevo Orden Informacional. Gubernamentalidad algorítmica y vigilancia genética" [1].
}

\section{Big data, digital footprints and fingerprints}

We refer, on this instance, to one of the aspects that concerns the existence and availability of so-called Big Data. Where does this Big Data stem from? It includes our footprints as users of any social network or smartphone, whether we used it to talk through, or to connect to a geopositioning application, such as Waze, Tinder or Google Maps. It may not only detect where we are going to, but how fast we are moving. Even if we type a message on some platform and erase it before having sent it, it may have been registered. Our credit card shopping history can also be tracked, as well as information registered by devices at our workplaces, from energy consumption to the workers' performance. All this information is stored by different companies (telephone, search engines, social networks, surveillance agencies, internet providers), and may be bought and sold, under different conditions depending on each country's regulations.

Different organizations can make use of this data. A quick search about "facial recognition" on the web can recall more than 70 bundles of data that are used, for example, in order to test these technologies and avoid their main weaknesses (defective illumination, changes in pose, use of makeup). The images that make up those databases, as informed by these sites themselves, were taken from web pages: from Wikipedia, Flickr, makeup tutorials uploaded by users to YouTube.

I would like to highlight that in the last years, these two kinds of print (digital footprints and fingerprints) have started to intertwine. An evident case are the images of the face: when we upload images to Facebook, this social network identifies the faces of the people that are in them and asks us if we would like to tag them. That means it can recognize who is present on those pictures. These images include biometric information that may be linked to the behavioral data we leave on the network. The same happens when we use our fingerprints to unlock a smartphone.

How much do these prints say about us? Let us take the case of the tracks we leave on Facebook, a data company with more than 2.000 million active users each month. ${ }^{4}$ That is to say, it collects data on a number of people greater than the population of the world's most populous country (China, with 1.388 million people in 2017). ${ }^{5}$ And that it gathers much more diverse, exhaustive and current data than any demographic statistic known yet.

Five years ago, a team lead by the Polish psychologist Michal Kosinski, then a doctoral student in psychometrics at

\footnotetext{
${ }^{4}$ Source: The company's own quarterly report. Facebook Reports Second Quarter 2017 Reports. Available at: https://investor.fb.com/investor-news/press-releasedetails/2017/Facebook-Reports-Second-Quarter-2017-

Results/default.aspx [Last access: June 2017.]

${ }^{5}$ Source: Internet Global Statistics and United Nations Population Division. Available www.un.org/en/development/desa/population.
} 
Cambridge University, showed that, based on a 68 "like" average by any given Facebook user, it was possible to predict their skin color (with a 95\% accuracy), their gender (93\%), their sexual orientation $(88 \%$ in males; $75 \%$ in females), and their political sympathies $(85 \%)$. It was also possible to establish their IQ, their religion, whether they used drugs or alcohol and even if their parents had separated [3]. On a second investigation, he was able to predict information on a person better than their friends, based on 70 "likes"; 150 were enough to surpass what their parents knew about them, and 300 "likes" were enough to outmatch their partners [4]. According to Hannes Grassegger and Mikael Krogerus on the Swiss publication Das Magazin, the day Kosinski published these findings, he received two phone calls: a threat of legal action and a job offering. Both from Facebook. [5]

I will leave the outline of this question, about whether what this data says about us may be considered a "faithful representation" of who we are and will take it up again towards the end. Next, I will approach two specific moments in the vast territory I am barely attempting to offer a glimpse of. My starting point will be two distinct pieces of information.

\section{Genetical identifications and "speculative interpretations"}

Information 1. In May 2016, the Mislata City Council in Valencia, Spain, issued an ordinance that compelled its citizens to extract genetic material from their dogs in order to create a canine DNA databank. The idea behind it is to enable the sanctioning of the pet owners who do not pick up their pets' excrement from the sidewalks. ${ }^{6}$

In order to do that, the licensed cleaning company would pick a sample of each piece of excrement it found on the municipality's streets and send it to a lab, where the sample would be matched against the Municipal Census' genetic databank in order to establish the dog's identity and, therefore, its owners'. Thus, the "uncivil" owners, as the press calls them, would pay fines of up to 200 Euros for the excrement they had not picked up, and of up to 300 if the dogs were not registered.

The practice is not entirely new. The biotechnology firm that patented the system, called Poo Prints, claims that over 2.500 communities in Great Britain, Canada and the United States of America already use this method. ${ }^{7}$

Information 2. The first time that the analysis of genetic material was applied during a criminal investigation was a little over thirty years ago. In 1986, Dawn Ashworth, a 15 year old woman, had been raped and killed in Leicestershire, England. Three years before, a similar crime had been

6 The ordinance's full text may be read here: www.mislata.es/rs/32026/d112d6ad-54ec-438b-93584483f9e98868/4db/fd/1/filename/WWW.MISLATA.ES. [Last access: December 15th 2016.]

${ }^{7}$ See: www.pooprints.com. [Last access: November 20th 2017.] carried out at a nearby locality, on the also 15 year old Lynda Mann. The DNA analysis performed on the semen samples found on the bodies showed that both crimes had been perpetrated by the same author, but their comparison to the genetic profile of the only suspect — who had plead guilty to the second murder- did not match. The test, in its judicial debut, proved the defendant's innocence.

The case was solved through the analysis of the genetic profiles of adult males residing in the area. A man of the locality, Colin Pitchfork, turned out to be the first serial rapist identified through a genetic test, achieved through a research of massive outreach.

Well then: in these two very different cases, we have the common occurrences of, on the one hand, genetic traces, and, on the other, a database, or, at least, a study that allows for a comparison. What if the database does not exist, and the efforts aimed at constructing it fail? This happens frequently, due to the fact that in the "real" world, the world of biological information, there are nodata banks exhaustive enough - although they are proliferating, as we have seen. That was the case in 2011, when Candra Alston and her daughter, Malaysia Boykin, were murdered in their Columbia apartment, in South Carolina (USA). Nobody registered the occurrence, there were no cameras that could provide clues about the murderer. The police collected DNA samples from more than 150 people, but the investigation stalled.

Forensic geneticists have been working on overcoming this limitation, and the technology to speculate about the possibility of reconstructing a face from traces of DNA has been in development for the last ten years. The technique is called forensic DNA phenotyping or phenotypification (FDP). FDP differs from DNA profiling in several aspects. First, the latter does not reveal personal information, but establishes whether two samples belong to the same person. FDP, on the contrary, uses the DNA sample taken from a certain place to create a possible image or identikit of someone who was there. Then, the DNA profile confirms the identity within a given universe of possible people, while FDP aims to predict the appearance of someone who is unknown or has not yet been found.

The first public appearance of this technique in the field of law enforcement was in January 2015, precisely to reopen the case of Alston and her daughter. That year, the Columbia Police Department acquired the services of Parabon-NanoLabs, whose program Snapshot was used to developed and publish the attackers possible identikit. ${ }^{8}$

Inquiries conducted with this method enable the acquisition of probabilistic data regarding sex, eye color, hair color and a controversial "ethnicity range" or "ancestry", which generates unease because it points out the return of a more or less covert notion of race, which seemed to have been overcome by the 1950 s, with the implicit risks of stereotyping and the exacerbation of discriminatory and

\footnotetext{
Parabon-NanoLabs press release may be seen here: nanolabs.com/news-events/2015/01/snapshot-puts-face-on-fouryear-old-cold-case.html. [Last access: July 25th 2017.]
} 
racist tendencies. ${ }^{9}$ They are unable to establish their age, because, as it is known, there are no DNA markers for age.

However, this information does not circulate only in scientific and forensic environments. We reach thus the opus of the artist Heather Dewey-Hagborg, an Information Arts graduate with advanced knowledge in computer programming, who participates in the so-called "biohacking" movement (or DIYbio, or garage biology), who, starting in 2012, decided to explore this practice, through techniques similar to those used by scientists.

In her series Stranger Visions (2012-2013), ${ }^{10}$ DeweyHagborg analyzed genetic material extracted from samples picked at public spaces, like chewing gum, hair or cigarette butts and created three dimensional portraits from the results. Working with Genspace, a DIYbio laboratory in New York, Dewey-Hagborg extracted DNA from the waste and processed it to concentrate on the strands that code for sex, eye, skin and hair color, ethnicity range, in addition to certain facial features such as the width of the nose and mouth. She put this data into a computer program and produced a prediction or speculative estimation of the possible facial features of the people that the genetic material had belonged to. As this technique does not enable to find out their ages, she depicted them at around 25 years of age. Then, she printed them on a 3D color printer.

Dewey-Hagborg started showing Stranger Visions in 2012. As a derivative of of the same action, and entering the bioactivist front of bioart, she started working the following year in "counter-surveillance" techniques, promoting the concealment of one's own DNA traces, in a strategy that recovers, in order to protect biologic data, the issue of anonymization in computer jargon (it is fit to remember that Dewey-Hagborg studied Information Arts). The first piece was DNA Spoofing, a video that displays ways of hiding genetic tracks. The following can be read on her webpage dedicated to this piece:

"As IP spoofing makes anonymous internet browsing possible, DNA spoofing extends that potential by scrambling genetic material, enabling anonymous physical trajectories in tandem with digital ones. In this spirit, our work offers some DIY techniques to counteract genetic surveillance." [6] ${ }^{11}$

In 2014, Dewey-Hagborg developed the project-product Be Invisible, which works as a DNA concealant. Be Invisible is a two spray kit, one called "Erase", another called "Replace". "Erase" eliminates 99,5\% of DNA material from any surface, while "Replace" hides the remaining $0,5 \%$ with a layer of arbitrary genetic material.

\footnotetext{
${ }^{9}$ See in particular the four declarations on the racial question by UNESCO (1969), drafted by specialists of different scientific disciplines in 1950, 1951, 1964 and 1967, as part of a program of said organization to encourage the scientific knowledge about race and fight racial prejudices

10 Documentation on the pieces may be seen here: http://deweyhagborg.com/projects/stranger-visions. [Last access: July 25th 2017]

11 Source: https://deweyhagborg.com/projects/dna-spoofing [Last access: July 25th 2107]
}

It is not difficult to imagine that this product could be used to hide a crime. In a personal communication with the artist, I asked how she interpreted the potential "non desired" uses of the piece, to which she responded: "That is actually a secondary aspect of the work." The central point, she added, is "to draw attention to the vulnerability of DNA evidence. To question its authority as a 'gold standard' of forensic science. If DNA can be pirated, created and 'planted' as any other evidence, does it deserve the high status it is granted?". ${ }^{12}$

The following year, Dewey-Hagborg was one of the main proponents of Biononumus.me, which she defines as a "center for community research on biologic surveillance", ${ }^{13}$ in whose website one may find resources to trick digital fingerprint identification systems or relatively funny instructions (make up, haridos) to avoid facial recognition.

To wrap up this section, allow me to comment on one additional case. In a use case that has nothing to do with forensics, but rather with a certain civilizational zeal, the advertising agency Ogilvy advised the Hong Kong authorities in 2015, and launched, using services provided by Parabon-Nanolabs, an environmental campaign called The Face of Litter. Their aim: to reduce the amount of litter resorting to tried-and-true public shaming. The campaign takes DNA samples found on the litter to predict the faces of those who have littered the streets and, supposedly, shame them publicly by divulging their faces on billboards, social networks and print publications.

And I say "supposedly", because, at this technique's current state of development, it is still far away from being able to accurately represent the face of the bearer of the sampled DNA. As Dewey-Hagborg has pointed out on different occasions, the faces produced with these technologies "slightly resemble" how the real consumers of the chewing gum or cigarettes could be. There is barely a "familiar air", as the artist herself states, "as if they were distant cousins" [7].

In 2015, the artist published in The New Inquiry a kind of documentary memoir of the work in which she wonders: "How valid are these DNA-derived portraits? How much do they resemble the DNA donor?" And she replies:

"Not very. Or more precisely, it may be accurate, to the extent that the individual resembles an average representation of their genetic traits and ancestry as it has been represented within the training data." [6].

This is thus because FDP may not account for age, nor environmental influence on gene expression, nor for the voluntary decisions on appearance: diet, hair color, makeup, surgeries. These images show what we could have been, had we not been exposed... to life. They are the reflection of a series of possibilities, which nonetheless lacks anything

\footnotetext{
12 Personal communication with the artist through email, March 23rd 2017.

${ }^{13}$ Source: http://biononymous.me [Last access: July 25th 2017]
} 
related to the correct and effective actualization of those possibilities.

\section{Error, art and resistance}

Emilio Vavarella is an Italian artist who has been researching the different roles the error plays in art and in technology for more than a decade. One of his central ideas is to observe technical errors closely, the errores not foreseen by the device, they "reveal the invisible technological mechanisms where that error originates" (p. 15) $[8]$.

For him, an artistic practice that makes conscious use of technical error requires a deep comprehension of technology; thus, using and studying the technological error "implies indirectly a greater comprehension of the logics of technological power" (p. 15) [8]. He proposes, then, to go beyond unforeseen errors, using them as a key for interpretation: "on one side, by illuminating the changing and apparently invisible mechanisms of technological power, and on the other, proposing innumerable opportunities to find new resistance strategies, based on the exploitation of the cracks and weak spots" (p. 15) [8] of technoscience.

In The driver and the cameras (2012), one of the three pieces that integrate his Google Trilogy, Vavarella puts these ideas at play when exhibiting a series of images where the - usually invisible - faces of the drivers of the cars that construct the documentation for Google Street View are actually exposed. In fact, each Google Street View car is equipped with a Dodeca 2360 camera with eleven lenses, which is able to photograph in 360 degrees. Afterwards, the pictures are assembled to create a stereoscopic view, while an algorithm developed by Google erases people's faces, whether they are on the street or driving the vehicles. In order to create his series, Vavarella searched for faces that had escaped Google Street View's algorithm. The eleven portraits he isolated "immortalize the driver of the Google car", as the artist affirms on his website: "His face is the symbol of an error yet at the same time shows a human side and, perhaps, the limits of technological power". ${ }^{14}$

Another interesting piece for our analysis is Pareidolia Digital: a personal index of erroneous Facebook portraits (2012-2013). In order to make it, Vavarella uploaded to Facebook all the images in his personal file: 30.000 files taken since 2005. Next, he stopped on each of them and registered the names Facebook would suggest with its facial recognition, searching for possible errors within the program. Facebook recognized 193 times a face where there was none. The technology would recognize something random and seemingly trivial, like a piece of cloth, a hand, a wall or a plant, as a face. Once he had gone through the

\footnotetext{
${ }^{14}$ Source: http://emiliovavarella.com/archive/google-trilogy/driverand-cameras. [Last access: November 2nd 2017]
}

process, Vavarella organized the mistakes into a "coherent system", ${ }^{15}$ which is what constitutes the piece.

\section{Some clues to wrap up}

Having arrived at this point, I will only pause on some of the many topics this necessarily reduced panorama proposes to our thought.

First, I will recover the question in the title of this communication: these attempts to identify and decypher do not need - even if they pretend to - to postulate a new scientific, philosophic, anthropologic or psychological definition of man. These digital doubles constitute, as Michel Foucault would say, in The Birth of Biopolitics referring to the figure of homo oeconomicus, "the contact surface between the individual and the power that is exerted on them" (p. 292) [9].

They are what enables powers to act on actions (or reactions). They do not define us, they do not faithfully represent us, much less do they comprise everything we are or could be: they simply (and none of this is obviously simple) work. That is: they work predicting and inducting our eventual behaviors, revealing our data to possible interested parties and identifying our whereabouts with or without our consent.

Secondly, in order to face these procedures, artists have attempted to develop different tactics. We have seen three of them here: the critical appropriation of technologies, the anonymization strategies for trajectories online or in "real" life (from IP invisibilization to makeup and voluntary selfdesign); and the "profanation" through unexpected uses, in this case, technical error.

In the first case, through critical appropriation of technologies, to turn them against their real or potential use, in the hands of technological and governmental powers, promoting an "unblackboxing" of their procedures, or using their errors to uncover the capture mechanisms of individuals and individuations, as well as to reveal the presence of powers not always "inexistent" or "immaterial", but human, all too human. They do so even assuming new risks, upon which it is important to keep reflecting.

In the case of anonymization strategies, searching to construct a new practice and a new pedagogy of distance and dissidence with regards to the attempts to capture and appropriate what is today called "prints", singular traces of our ways of being in the world. And in the reappropriation strategies of the technological error, not with an intention to correct it, but to open up the possibility of something new: to recover the power of bodies and of thought, something that is never entirely available in a "database", to raise the question once and again about what is, beyond and before our data, the singularity of the living.

Profanating, as the Italian Giorgio Agamben reminds us, meant to the Roman jurists "to return to the free use of men"

15 Source: http://emiliovavarella.com/archive/digital-pareidolia. [Last access: November 2nd 2017] 
what had been withdrawn to a separate sphere (p.97) [10]. Profanating a technical device by defying those discourses and practices that incite us to understand ourselves as "data bundles", as supports for predictable, modulable, operationalizable information is -these pieces seem to suggest - one of the inescapable duties of art and thought in our time.

\section{References}

[1] Costa, F. (2017) Omnes et singulatim en el nuevo orden informacional Gubernamentalidad algorítmica y vigilancia genética. Poliética. Revista de Ética e Filosofia Política V(1).

[2] Foucault, M. (2006) Seguridad, Territorio, Población (Buenos Aires: FCE)

[3] Kosinski, M.; Stillwell, D. and Graepel, T. (2014) Private traits and attributes are predictable from digital records of human behavior. Proceedings of the National Academy of Sciences 110(15): 5802-5805.

[4] Youyou, W.; Kosinski, M. AND Stillwell, D. (2015) Computer-based personality judgments are more accurate than those made by humans. Proceedings of the National Academy of Sciences, 112(4): 1036-1040.

[5] Grassegger, H. AND Krogerus, M. (2016) Ich habe nur gezeigt, dass es die Bombe gibt. Das Magazin, (48).
[6] Dewey-Hagborg, H. (2015) Sci-Fi Crime Drama With a Strong Black Lead. The New Inquiry. Available at: https://thenewinquiry.com/sci-fi-crime-drama-with-a-strongblack-lead/

[7] Martialay, M. (2013) Stranger Visions. Interview with Heather Dewey-Hagborg. The approach. Discovery, innovation and imagination at Rensselaer Polytechnic Institute. Available at: http://approach.rpi.edu/2013/04/11/stranger-visions

[8] VAVARELla, E. (2015) Art, Error, and the Interstices of Power. Journal of Science and Technology of the Arts 7(2).

[9] Foucault, M. (2007) Nacimiento de la biopolitica (Buenos Aires: FCE).

[10] Agamben, G. (2005) Elogio de la profanación. In Profanaciones (Buenos Aires: Adriana Hidalgo), pp. 97-119. 